\title{
PENGEMBANGAN PERANGKAT MODEL COOPERATIVE SCRIPTS DALAM PEMBELAJARAN IPA UNTUK MENINGKATKAN PEMAHAMAN KONSEP IPA DAN KETERAMPILAN BERKOMUNIKASI SISWA DI SEKOLAH DASAR
}

\author{
Dian Eka Indriani ${ }^{1)}$, Tjandrakirana ${ }^{2)}$, Muslimin Ibrahim $^{3)}$ \\ ${ }^{1)}$ Program Studi Pendidikan Dasar, Program Pascasarjana Universitas Negeri Surabaya \\ ${ }^{2), 3)}$ Dosen Pascasarjana Prodi Pendidikan Sains Univesrtitas Negeri Surabaya \\ E-mail: dianindriani79@gmail.com
}

\begin{abstract}
A Research developement of Teaching and Learning Science materials has been done in Elementary School, using Cooperative Sripts with 4D model modification and aimed to increase the students' science concept understanding and communication skill at Elementary school main subject humans' respiration system. Data was analyzed by qualitative and quantitative description. The research appeared that the validation of learning and teaching materials is valid, the learning implementation is good (3.97), active student centered activity. The result of student understanding outcomes were analyzed by N-gain metode shows improvement of The Students' scince concept understanding (0.65) as well communication skill (3.8) along with students' affective asessment outcomes show good result (3.9). Conclucion of this research, appears that Learning and teaching materials Cooperative Scripts' model is feasible, influence and able to increase students' science concept understanding and communication skill outcomes as well.
\end{abstract}

\section{Keywords: Cooperative, Cooperative Script, Concepts Understanding, Communication Skill}

\begin{abstract}
Abstrak: Telah dilakukan penelitian pengembangan perangkat pembelajaran IPA di Sekolah Dasar model Cooperative Scripts dengan 4D modifikasi yang bertujuan meningkatkan pemahaman konsep IPA dan keterampilan berkomunikasi siswa pada pokok bahasan materi sistem pernapasan manusia. Data dianalisis secara deskriptif kualitatif dan deskriptif kuantitatif. Hasil penelitian menunjukkan perangkat pembelajaran valid, keterlaksanaan pembelajaran baik (3.97), kegiatan berpusat pada murid aktif. Hasil tes pemahaman konsep siswa dianalisis dengan N-gain menunjukkan pemahaman konsep IPA siswa meningkat (0.65) begitu pula dengan keterampilan berkomunikasi (3.8) sejalan dengan hasil penilaian afektif siswa menunjukkan hasil yang baik (3.9). Simpulan penelitian ini, bahwa perangkat pembelajaran IPA model Cooperative Scripts layak, dapat meningkatkan dan berpengaruh secara signifikan terhadap pemahaman konsep IPA dan keterampilan berkomunikasi siswa di Sekolah Dasar.
\end{abstract}

Kata kunci: Kooperatif, Cooperative Scripts, Pemahaman Konsep, Keterampilan Berkomunikasi

\section{PENDAHULUAN}

Sistem pendidikan di Indonesia telah mengalami banyak perubahan sebagai usaha peningkatan kualitas pendidikan di Indonesia. Salah satunya adalah pembentukan kurikulum 2013. Sejalan dengan pembaharuan tersebut, terdapat upaya konstruktif dalam rangka meningkatkan mutu pendidikan dan pengajaran, terutama dalam pemahaman konsep mata pelajaran IPA yang dalam kurikulum 2013 merupakan salah satu mata pelajaran di sekolah dasar yang diintegrasikan ke dalam mata pelajaran lainnya seperti bahasa Indonesia.

Sesuai tujuan pembelajaran IPA berupa produk, konsep, dan proses yang saling berhubungan untuk mencapai tujuan sikap sosial IPA, maka penting sekali pemahaman konsep IPA pada siswa sekolah dasar, namun banyak di antaranya pemahaman yang dimiliki siswa sama sekali berbeda dengan konsep ilmiah yang diakui kebenarannya (Ibrahim, 2012).

Pemahaman konsep dapat diperoleh dengan keterampilan berkomunikasi karena dengan keterampilan berkomunikasi akan melibatkan proses berpikir (Arends, 2008), tetapi pada faktanya kebanyakan anak-anak sulit mengungkapkan ide atau berkomunikasi dengan baik, oleh karena itu yang diperlukan bukanlah hanya media, namun juga sumber belajar yang dapat memberikan cakrawala yang mampu menunjang kemampuan dalam aspek mendengarkan dan berbicara (Sharan, 2102) dan juga model pembelajaran yang sesuai untuk dapat mencapai tujuan pembelajaran IPA tersebut di atas.

Model pembelajaran Cooperative Scripts mencakup keterampilan berkomunikasi dan pemahaman konsep sehingga dapat mencapai tujuan pembelajaran IPA di atas, sejalan dengan pendapat Presseisen (1992, 
dalam Slavin, 2009) bertukar gagasan dan mendiskusikannya dalam kelompok kooperatif juga memberikan lingkungan yang kondusif dan menciptakan pendekatan yang menyenangkan terhadap perkembangan konseptual.

Komunikasi dalam metode Cooperatif Scripts yang dikembangkan Dansereau dan koleganya (1994), dalam Slavin (2009) menata langkah-langkah komunikasi sehingga membuat siswa dapat lebih mudah berkomunikasi dan menguasai materi pelajaran, karena keunggulan dalam model ini adalah siswa secara berpasangan melatih berkomunikasi sambil belajar mengenai konsep sehingga dapat mengingat lebih jauh terutama pada inisiasi awal.

Siswa melalui pembelajaran model Cooperative Scripts dapat lebih mudah memahami penjelasan dari kawannya dengan memakai bahasa pergaulannya sendiri dikarenakan taraf pengetahuan serta pemikiran mereka yang sejalan dan sepadan" (Miller, 2008). Teknik pembelajaran Cooperative Script ini mendorong keaktifan siswa pada saat pembelajaran yang meliputi keberanian siswa dalam mengungkapkan ide yang mereka miliki, keberanian dalam mengajukan pertanyaan, melatih daya ingat siswa, serta kecepatan mereka dalam berpikir (Ginnis, 2008).

\section{METODE PENELITIAN}

\section{A. Subyek Penelitian}

Subyek penelitian ini adalah 22 siswa kelas V dalam kelas tunggal di Sekolah Dasar Negeri Banyuajuh 2 Kamal di akhir semester tahun 20142015.

\section{B. Desain Uji Coba}

Penelitian ini adalah penelitian pengembangan dengan menggunakan One-Group Pretest-posttest design (Fraenkel, 2008) dengan desain sebagai berikut:

\section{$\mathrm{O} 1 \mathrm{X} \mathrm{O} 2$}

Keterangan:

$$
\begin{aligned}
& \mathrm{O} 1=\text { Pre Test } \\
& \mathrm{X}=\text { Perlakuan model Cooperative Scripts } \\
& \mathrm{O} 2=\text { PostTest }
\end{aligned}
$$

\section{Prosedur Penelitian}

Prosedur penelitian ini terdiri atas 2 tahap, yakni tahap I merupakan tahap pengembangan perangkat pembelajaran, dan tahap II merupakan tahap uji coba/implementasi perangkat pembelajaran dengan model 4D menurut Thiagarajan, et al.,1974 dalam Trianto (2007), pada penelitian ini dilakukan sampai tahap 3D.

Fase pengembangan perangkat: Aktivitas yang dilakukan dalam fase pengembangan ini adalah membuat perangkat pembelajaran dan instrumen penelitian. Perangkat pembelajaran meliputi silabus, Rencana pelaksanaan pembelajaran, Lembar Kegiatan Siswa, Buku Siswa dan Instrumen Penilaian Siswa dan validasi

konstruk dan isi perangkat oleh para pakar.

Fase Implementasi pembelajaran: implementasi perangkat pembelajaran meliputi keterlaksanaan rencana pelaksanaan pembelajaran.

\section{Tehnik Pengumpulan Data}

Tehnik pengumpulan data penelitian ini dilakukan dengan beberapa cara, yaitu observasi, tes dan angket. Observasi dilakukan untuk mengumpulkanbdata penelitian keterlaksanaan Rencana Pelaksanaanbdan Keterampilan Berkomunikasi serta penilaian afektif siswa yang dilakukan oleh dua orang pengamat. Tes dilakukan untuk mengukur hasil belajar siswa yaitu peningkatan pemahaman konsep IPA, serta sensitivitas tiap butir soal. Angket dilakukan untuk mengumpulkan informasi tentang pemahaman konsep IPA siswa, data respon siswa terhadap kegiatan pembelajaran dan penilaian dari pakar.

\section{E. Tehnik Analisis Data}

Data hasil penelitian di analisis secara deskriptif kualitatif. Data yang dianalisis meliputi pemahaman konsep IPA siswa, Keterampilan berkomunikasi siswa, pengaruh penerapan model Cooperative Scripts terhadap pemahaman konsep IPA siswa. Data dari hasil pretes dan postes pemahaman IPA siswa dianalisi dengan CRI dan N-gain Score untuk mengetahui peningkatan pemahaman konsep IPA siswa. Pengaruh penerapan model Cooperative Scripts di analisis dengan uji-T (Amir, 2006).

Data kelayakan perangkat dianalisis atas rata-rata skor penilaian dua orang pakar/validator meliputi konstuk dan isi perangkat pembelajaran secara empiris. Data dari keterlaksanaan rencana pelaksanaan pembelajaran dianalisis dari rata-rata skor penilaian dari dua ornag pengamat.

\section{HASIL PENELITIAN DAN DISKUSI}

Berdasarkan analisis hasil penelitian perangkat pembelajaran dan analisis hasil implementasi perangkat pembelajaran model Cooperative Scripts pada uji coba yang telah dilakukan, dikemukakan pembahasan sebagai berikut.

\section{A. Validitas Perangkat Pembelajaran yang dikembangkan.}

1. Validitas Rencana Pelaksanaan Pembelajaran.

Rencana pelaksanaan pembelajaran dikembangkan sebagai panduan oleh guru dalam mengajarkan pemahaman konsep dan keterampilan berkomunikasi 
siswa melalui pembelajaran model Cooperative Scripts dengan mengacu pada kurikulum 2013 yang menerapkan pendekatan scientific sesuai permendiknas no. $81 \mathrm{~A}$ yakni memadukan taksonomi Bloom dan Krathwohl serta keterampilan dari Dyers.

Adanya kesesuaian dengan model Cooperative Script yaitu pada 5M terakhir adalah mengkomunikasikan, maka tidak dipilih pendekatan konseptual untuk memperoleh pemahaman konsep, didukung dengan teori dari pembelajaran konsep yang utama adalah "membawa sesuatu ke kelompok tertentu ke dalam kelas" dan meminta siswa untuk mengenal anggota lain dari kelompok ini (Gagne, 1993 dalam Ibrahim, 2012).

Rencana pelaksanaan pembelajaran yang dikembangkan telah divalidasi oleh dosen ahli pendidikan untuk mengetahui kebenaran format konstruk dan isi RPP meliputi aspek tujuan pembelajaran, kegiatan pembelajaran, waktu, perangkat pembelajaran dan bahasa mendapatkan skor rata-rata 3.95 dengan kriteria baik. Hal ini menunjukkan bahwa Rencana Pelaksanaan Pembelajaran yang dikembangkan adalah layak untuk diimplementasikan di sekolah.

\section{Validitas Lembar Kegiatan Siswa}

Lembar kegiatan siswa dikembangkan berdasarkan dengan materi dan strategi pembelajaran yang digunakan. Lembar kegiatan siswa yang dikembangkan berisi permasalahan dengan topik yang berbeda pada tiap-tiap pertemuan. Lembar kegiatan siswa yang dikembangkan mengarah pada pembelajaran IPA model Cooperative Scripts dengan pendekatan scientific yang bertujuan untuk meningkatkan pemahaman konsep siswa dan melatihkan keterampilan berkomunikasi siswa sesuai dengan Slavin (2008) Cooperative Scripts adalah pembelajaran kooperatif dimana siswa bekerja berpasangan dan bergantian secara oral meringkas bagian dari materi yang dipelajari.

Dalam lembar kegiatan siswa pada masing masing pertemuan berisi kegiaan mendasar yang harus dilakukan siswa untuk memaksimalkan pemahaman konsep melalui model Cooperative Scripts. Lembar kegiatan siswa pada pertemuan pertama berisi tentang materi alat pernapasan pada manusia, Lembar kegiatan siswa pada pertemuan kedua berisi tentang materi proses pernapasan pada manusia dan lembar kegiatan siswa pada pertemuan ketiga berisi tentang materi gangguan pada alat pernapasan manusia.

Sejalan pendapat Sharan (2012) Sebagai teman berpasangan, siswa mempraktikkan keterampilanketerampilan mendengarkan. Mereka terlibat dalam pemecahan masalah dan menganalisis cara berpikir mereka sendiri, menerima umpan balik dan arahan teman. Lembar kegiatan siswa yang dikembangkan telah divalidasi oleh tiga pakar dosen ahli untuk mengetahui kebenaran format dan isi untuk mengetahui keterlaksanaan LKS. Rata-rata hasil validasi dari para pakar lingkungan dan pendidikan meliputi aspek petunjuk, kelayakan isi, keterampilan berkomunikasi, prosedur dan pertanyaan mendapatkan skor rata-rata 3.9 dengan kriteria. Dari skor validasi tersebut dapat diketahui bahwa lembar kegiatan siswa yang dikembangkan dapat dinyatakan layak untuk diimplementasikan di sekolah.

\section{Validitas Materi Ajar}

Materi ajar yang dikembangkan digunakan sebagai sumber belajar bagi siswa dalam mempelajari materi tentang sistem pernapasan pada manusia. Selama uji coba, masing-masing siswa diberikan materi ajar. Guru membimbing siswa untuk menemukan informasi yang penting yang diperlukan selama proses belajar mengajar. Materi ajar yang dikembangkan terdiri atas tiga sub bab materi yaitu alat pernapasan pada manusia, proses pernapasan pada manusia dan gangguan saluran pernapasan pada manusia (Guyton, 2012). Materi ajar juga dilengkapi dengan kosakata sains berisi kumpulan kata atau istilah yang harus dipahami oleh siswa untuk mendukung proses pemahaman materi, gambar dan ilustrasi berfungsi sebagai sarana membantu pemahaman materi, beberapa aktivitas siswa berisi kegiatan yang berfungsi sebagai sarana untuk menerapkan pemahaman konsep IPA serta rangkuman berfungsi sebagai sarana bagi siswa agar dapat memahami garis besar materi dalam satu subtema yang dibahas, uji kemampuan berisi soal uraian pemahaman konsep.

Materi ajar yang dikembangkan telah divalidasi oleh dua dosen ahli materi dan atas arahan dosen pembimbing. Rata-rata hasil validasi dari para pakar untuk mengetahui kebenaran konstruk dan isi serta format meliputi aspek cakupan materi, tehnik penyajian, kelengkapan penyajian, kesesuaian dengan RPP, LKS dan tes pemahaman konsep, cakupan bahasa, cakupan manfaat pembelajaran mendapatkan skor ratarata 4.62 dengan kriteria sangat baik, dari skor validasi tersebut dapat diketahui bahwa materi ajar yang dikembangkan adalah layak untuk diimplementasikan di sekolah. Kelayakan materi ajar berdasarkan panduan BSNP mengenai kriteria materi ajar yang meliputi kelayakan konstruk dan isi, komponen kebahasaan dan komponen penyajian.

\section{Validitas Tes Pemahaman Konsep}

Tes pemahaman konsep dikembangkan untuk mengetahui seberapa jauh siswa mencapai pemahaman konsep setelah penerapan perangkat pembelajaran model Cooperative Scripts yang dikebangkan. Tes 
pemahaman konsep dilakukan dua kali yaitu dengan menggunakan pretes dan postes dilengkapi dengan kisi-kisi yang disusun mengacu pada taksonomi Bloom dan kematangan usia atau teori kognitif Piaget (Munthe,

2011).

Tes pemahaman konsep merupakan perangkat yang dipergunakan untuk mengetahui kemampuan daya serap siswa yang digambarkan dengan ketuntasan hasil belajar pada indikator yang telah dikembangkan, Ketercapaian ini didasarkan pada KKM yang telah di tentukan oleh SDN Banyuajuh 2 yaitu sebesar $70 \%$. Lembar penilaian yang dikembangkan berisi soal yang bersifat melatih pemahaman konsep siswa.

Tes pemahaman konsep divalidasiboleh dua validator dari dosen ahli pendidikan. Hasil dari validator memberikan penilaian valid tanpa revisi dan sebagian soal mendapatkan kategori baik dengan revisi kecil, ini menunjukkan bahwa tes pemahaman konsep yang dikembangkan adalah layak untuk diimplementasikan di sekolah. Kelayakan berdasarkan pada kesesuaian antara indikator, tujuan dan rumusan soal dengan kategori valid dengan revisi kecil karena pemilihan kesesuaian gambar.

\section{B. Proses dan Hasil Pembelajaran}

1. Keterlaksanaan Pembelajaran.

Implementasi Rencana Pelaksanaan Pembelajaran (RPP) mengacu pada kurikulum 2013 dengan model Cooperative Scripts untuk melatih keterampilan berkomunikasi dan meningkatkan pemahaman konsep IPA siswa di Sekolah Dasar, pendekatan yang dipakai adalah scientific approach merujuk permendiknas no. $81 \mathrm{~A}$ dan adanya kesesuaian dengan model Cooperative Script yaitu pada $5 \mathrm{M}$ terakhir adalah mengkomunikasikan, didukung dengan teori dari pembelajaran konsep yang utama adalah "membawa sesuatu ke kelompok tertentu ke dalam kelas" dan meminta siswa untuk mengenal anggota lain dari kelompok ini (Gagne, 1993 dalam Ibrahim, 2012).

Sejalan dengan Arends bahwa pemahaman konsep dapat diperoleh dengan keterampilan berkomunikasi karena dengan keterampilan berkomunikasi akan melibatkan proses berpikir. Ada hubungan yang kuat antara bahasa dan berpikir, keduanya menghasilkan kemampuan untuk menganalisi, untuk menalar secara deduktif dan induktif, dan membuat inferensi yang masuk akal, berdasarkan pengetahuan (Arends, 2008).

Kesesuaian antara metode dengan aktivitas siswa tidak lepas dari keterlaksanaan tahap-tahap pembelajaran yang telah dirancang. Terlaksananya tahap-tahap pembelajaran dengan baik sangat mempengaruhi aktivitas siswa dalam pembelajaran (Munthe, 2011).
Pertemuan Kegiatan Belajar Mengajar di dalam penelitian ini dilakukan 3 kali dan pada setiap kali pertemuan diamati oleh 2 orang pengamat yang sudah diberikan penjelasan/pelatihan singkat terlebih dahulu. Aspek yang diamati secara keseluruhan meliputi pendahuluan, inti, penutup, pengelolaan waktu dan suasana kelas. Berdasarkan data yang dapat diketahui rata-rata kemampuan guru dalam melaksanakan pembelajaran berkategori baik dengan rata-rata skor dari dua orang pengamat adalah 3.98, hasil pengamatan keterlaksanaan RPP mendapat skor keterlaksanaan dalam kategori reliabel sebesar 99,3\%.

Reliabilitas ini menunjukan kemantapan (konsistensi keterlaksanaan pembelajaran) apabila RPP ini diujikan kedua kalinya yaitu pada uji coba sesungguhnya dengan perangkat yang sama akan mendapatkan hasil yang relatif sama. Hal ini sesuai dengan Ibrahim (2005) yang menjelaskan bahwa setiap pengukuran selalu mengandung kesalahan dalam pengukuran, maka pengukuran yang diulang pada waktu yang berbeda tidak pernah memberikan hasil yang persis sama.

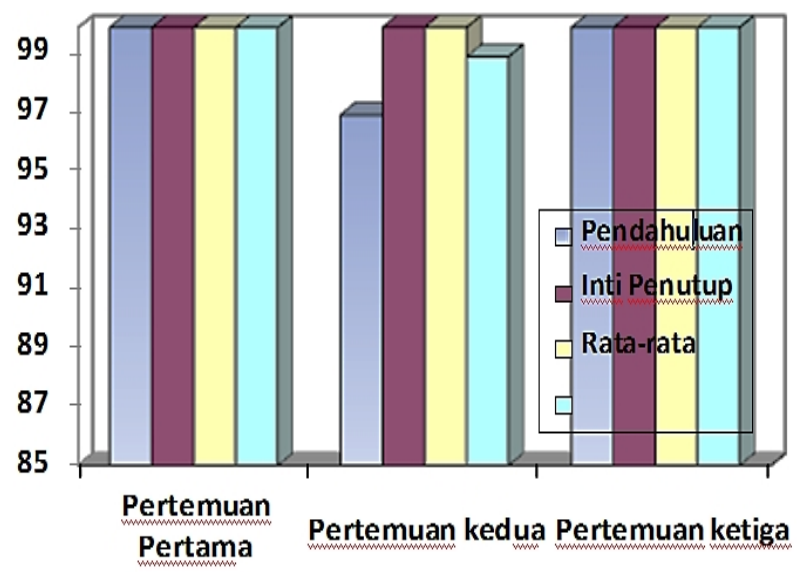

Gambar 1. Diagram keterlaksanaan RPP

\section{Keterbacaan Materi Ajar}

Materi ajar yang dikembangkan mendapatkan tingkat keterbacaan yang baik yang berarti bahan ajar yang dikembangkan sesuai dengan karakteristik perkembangan intelektual siswa yakni berdasarkan prosedur Fry dan grafik Fry, berdasarkan hasil perhitungan per seratus kata dari 3 buah sample wacana dalam materi ajar, diperoleh angka 5 sebagai hasil titik temu antara baris vertikal dan horizontal dalam grafik FRY yang menunjukkan angka kesesuaian tingkat kelas pembaca.

Hal ini berarti bahan ajar yang dikembangkan sesuai dengan karakteristik perkembangan intelektual operasional formal yakni pada siswa kelas 5 Sekolah Dasar, pada tahap ini kemampuan kognitif siswa sudah berkembang secara signifikan akan tetapi masih bersifat terbatas (Dimyanti, 2009). 
Anak pada tahap ini sudah mulai mengambil keputusan berdasarkan pengalaman nyata dan berpikir lebih abstrak, idealis dan logis. Hal ini tidak menjadikan masalah pada siswa meskipun pada materi ajar mengajak siswa untuk berpikir pada tingkat tinggi. Siswa merasa mampu dan senang dalam mempelajari materi ajar teresebut, sehingga siswa mampu memahami materi ajar yang telah dikembangkan.

\section{Keterampilan Berkomunikasi Siswa}

Berdasarkan hasil pengamatan keterampilan berkomunikasi siswa, diketahui bahwa aktivitas siswa yang menonjol adalah aktivitas siswa dalam berkomunikasi baik secara tulisan yaitu meringkas dan secara lisan khususnya membacakan ringkasan, menjelaskan materi, berdiskusi, mengemukakan pendapat, tanya jawab antara siswa (Degeng, 2003).

Data ini menunjukkan bahwa menggunakan model pembelajaran Cooperative Scripts lebih berpusat pada siswa dimana siswa lebih banyak dilibatkan dalam penggalian konsep yang diperlukan untuk meningkatkan pemahaman konsep IPA bahkan meremediasi miskonsepsi.

Hal ini sangat relevan karena metode Cooperative Scripts yang digunakan adalah menekankan pada proses pemahaman konsep melalui keterampilan berkomunikasi siswa, dengan demikian dominasi guru dalam pembelajaran dapat dikurangi melalui kegiatan siswa dalam langkah-langkah Cooperative Scripts (Sharan, 2012).

Sesuai dengan pendapat (Dansereau, 1985 dalam Kiranawati, 2007) banyak siswa merasakan manfaat bekerja sama dengan teman sekelas mendiskusikan materi yang telah mereka baca atau mereka dengar di kelas atas latihan teman sebaya. Siswa dapat saling berdiskusi, berkomunikasi, membantu mempelajari informasi atau keterampilan. Tanggung jawab tersebut berpengaruh positif terhadap hasil belajar siswa.

Diskusi yang dilakukan siswa untuk menganalisis data dan menanggapi presentasi dari kelompok lain, hal ini mencerminkan keterampilan sosial berkomunikasi siswa meningkat. Diskusi ini mempunyai peran penting dalam pemahaman konsep siswa, dengan diskusi pada setiap kelompok dapat membantu anggota kelompok yang belum sepenuhnya memahami konsep yang dipelajari, dengan cara ini sebenarnya siswa belajar melalui interaksi dengan teman sebaya sehingga siswa dengan kemampuan tinggi akan terbuka untuk membantu siswa lain sehingga terjadi proses belajar yang lebih mudah (Nur, 2010).

\section{Pemahaman Konsep IPA Siswa}

Peningkatan pemahaman konsep IPA siswa dapat dilihat dari hasil tes pemahaman konsep siswa yang diukur dengan menggunakan CRI dan $\mathrm{N}$-gain skor, $\mathrm{N}$ gain menunjukkan perbedaan pemahaman konsep siswa sebelum dan sesudah diberikan perlakuan. Gain skor ternormalisasi menunjukkan tingkat efektivitas perlakuan daripada perolehan skor dari postes. CRI menunjukkan tingkat keyakinan siswa dalam menjawab soal pretes dan postes yang dipadukan dengan akurasi jawaban, kemudian poin yang diperoleh mengacu pada tabel skor kriteria CRI (Ibrahim, 2012).

\section{a) Hasil Tes Pemahaman Konsep IPA Siswa}

Hasil dari penelitian menunjukkan adanya peningkatan hasil tes pemahaman konsep IPA siswa di dalam postes. Sesuai pendapat Arends (2008) yang menyatakan pemahaman konsep dapat diperoleh dengan keterampilan berkomunikasi karena dengan berkomunikasi akan melibatkan proses berpikir, ada hubungan antara bahasa dan berpikir, keduanya menghasilkan kemampuan untuk menganalisi, untuk menalar secara deduktif dan induktif, dan membuat inferensi yang masuk akal, berdasarkan pengetahuan,

Peningkatan hasil tes pemahaman konsep IPA siswa dapat dilihat di dalam diagram berikut ini:

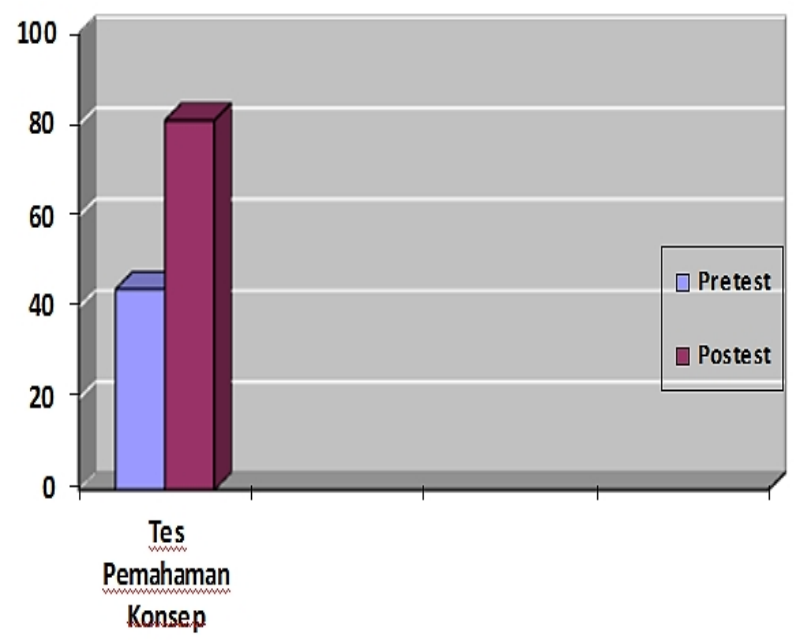

Gambar 2 Diagram Hasil Tes Pemahaman IPA Siswa

Hasil pelaksanaan postes dari 22 orang siswa yang mengikuti tes, seluruh siswa tuntas (100\%), dan secara ketuntasan klasikal siswa (100\%), hal ini ditunjukkan dengan peningkatan yang signifikan dengan keseluruhan nilai perolehan $\mathrm{N}$-gain siswa sebesar 0.65 , yang artinya terdapat peningkatan hasil belajar dengan kategori sedang. Hal ini juga sesuai dengan pengukuran indeks sensitivitas pada soal yang dikembangkan secara rata-rata menunjukkan hasil indeks 0.3 yang artinya sensitif (Ibrahim, 2005).

Hasil tes pemahaman konsep IPA siswa di analisis dengan N-Gain untuk mengetahui pemerolehan besarnya pemahaman konsep IPA siswa. Nilai N-Gain yang diperoleh 0.65 yang menunjukkan bahwa adanya peningkatan pemahaman konsep IPA siswa dengan kategori sedang. Analisis dari N-Gain juga

Pengembangan Perangkat Model Cooperative Scripts dalam ... 
menunjukkan adanya perbedaan antara sebelum dan sesudah penerapan model Cooperative Scripts.

\section{b) Uji Statistik}

Uji statistik dilakukan sebagai tambahan untuk menegaskan adanya perbedaan hasil tes pemahaman konsep siswa setelah diterapkan model pembelajaran Cooperative Scripts dan adanya pengaruh penerapan model Cooperative Scripts terhadap peningkatan hasil tes pemahaman konsep IPA Siswa. Uji statistik menggunakan Paired T-test dengan memakai SPSS 20.

Hasil uji statistik menunjukkan bahwa pengolahan data yang dilakukan melalui uji Saphiro-Wilk test untuk mengetahui distribusi normal tes pemahaman konsep, diperoleh rata-rata nilai sig (2-tailed) $0,708>\alpha=0,05$ yang berarti bahwa kelas dengan penerapan model pembelajaran kooperatif dengan penerapan model pembelajaran Cooperative Scripts berdistibusi normal sebagai syarat untuk dilakukan uji beda dengan uji paired-T test dengan menggunakan SPSS 20.

Pengujian homogenitas varians dilakukan dengan menggunakan uji levene's test, menunjukkan bahwa penerapan model pembelajaran Cooperative Scripts setelah dilakukan analisis data diperoleh nilai sig-hitung $=0,445>$ sig-tabel $(\alpha)=0,05$ yang artinya dapat disimpulkan bahwa kelas dengan penerapan model pembelajaran Cooperative Scripts memiliki varian yang sama atau homogen, sehingga telah memenuhi syarat untuk dilakukan analisis dengan uji-T.

Hasil uji-T menunjukkan sig-hitung $=0,02<$ sig. $\alpha$ $=0,05$ yang artinya terdapat perbedaan hasil belajar yang signifikan antara kelas dengan penerapan model pembelajaran Cooperative Scripts, sehingga diasumsikan bahwa penerapan model Cooperative Scripts berpengaruh signifikan terhadap Pemahaman Konsep IPA Siswa (Amir, 2006).

\section{c) Hasil Tes CRI Siswa}

Berdasarkan hasil analisis CRI pemahaman konsep IPA siswa diperoleh hasil temuan dalam penelitian ini bahwa model Cooperative Scripts dapat meningkatkan pemahaman konsep IPA siswa dengan cukup signifikan.

Hal ini dapat dilihat baik dari hasil tes pemahaman konsep berdasarkan hasil tes pretes dan postes siswa, diketahui bahwa peningkatan pemahaman siswa ditilik dari akurasi jawaban butir per butir soal maka diperoleh nilai $\mathrm{N}$-Gain dari butir soal yang menunjukkan skor sebesar 0.65. Peningkatan pemahaman konsep IPA siswa dapat dilihat dalam diagram berikut.

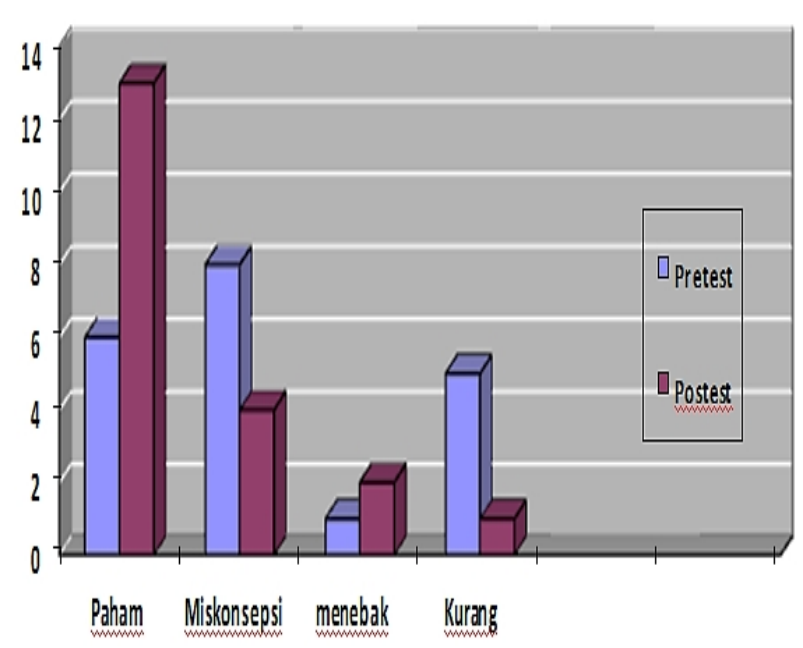

Gambar 3 Diagram Pemahaman Konsep Siswa

Berdasarkan gambar 3 Diagram Pemahaman Konsep Siswa di atas, menunjukkan keefektivitasan pembelajaran dengan model Cooperative Scripts ataupun pengukuran berdasarkan keyakinan siswa yang dipadukan dengan akurasi jawaban tes merujuk padatabel matrik keputusan CRI. Pemerolehan nilai Ngain dalam peningkatan skor CRI menunjukkan adanya peningkatan pemahaman konsep yang benar (0.74), adanya remediasi miskonsepsi $(-0,44)$, penurunan jumlah siswa menjawab salah karena kurangnya pengetahuan (-0.39). Sejalan dengan Sharan (2012) yang menyatakan tehnik kooperatif ini menata diskusi yang diperlukan untuk membantu siswa memahami konsep ilmiah (Hakim, A., Liliasari., dan Kadarohman, A., 2012).

\section{Penilaian afektif siswa}

Penilaian afektif siswa yang diamati pada penelitian ini adalah kompetensi K1 dan K2 dalam kurikulum 2013 yakni meliputi kedisiplinan, kejujuran, bersyukur, rasa ingin tahu, kerja sama dan menghargai guru/teman. Aspek kedisiplinan yang diamati yaitu dalam hal kedisiplinan dalam menyelesaikan kegiatan dan soal dalam LKS, tepat waktu memasuki kelas untuk mengikuti pelajaran.

Aspek jujur yang diamati yaitu kejujuran dalam mengerjakan tugas dan tes pemahaman konsep, sedangkan kriteria rasa ingin tahu, bersyukur, kerjasama dan menghargai teman/guru teramati dalam kerja kelompok dalam bentuk antusiasme siswa saat berdiskusi dan saat siswa berperan sebagai guru, penilaian berdasarkan skor dari rubrik afektif siswa.

Pada pertemuan pertama ditemukan rata-rata setiap aspek disiplin mendapat rata-rata skor lebih rendah terutama pada aspek kejujuran dan kerja sama siswa, disebabkan kekurangnya waktu siswa dalam mengerjakan LKS dan masih belum terbiasa dengan model pembelajaran baru. Kedisiplinan dan kejujuran sangat diperlukan dalam kegiatan belajar 
mengajar menurut Slavin (2011), jika memungkinkan dan harus selalu ada, kalimat atau tindakan disiplin hendaknya tidak mengganggu aliran pelajaran. Hal ini sangat berpengaruh terhadap proses kegiatan belajar mengajar, jika tingkat kejujuran dan kedisiplinan siswa tinggi kegiatan pembelajaran dapat berjalan dengan lancar, informasi yang diberikan oleh guru diterima dengan baik sehingga hasil belajar siswa menjadi baik.

Hasil penilaian afektif ini dapat dikembangkan melaui pembelajaran kooperatif. Sesuai yang di kemukakan oleh Felder (2007), bahwa kemampuan afektif siswa dapat ditingkatkan melalui pembelajaran kooperatif. Menurut Kardi (2005) berpikir mencakup komponen kognitif dan afektif. Dalam menentukan penerapan keterampilan berpikir untuk memecahkan masalah, komponen kognitif dan komponen afektif dapat sangat terintegrasi dan menghasilkan tujuan pembelajaran yang khusus.

\section{Respon Siswa}

Respons siswa terhadap kegiatan pembelajaran diketahui dari data hasil pengisian angket setelah mengikuti pembelajaran. ditemukan bahwa pendapat siswa terhadap model pembelajaran Cooperative Scripts untuk melatih keterampilan berkomunikasi dan meningkatkan pemahaman konsep IPA secara umum membuat siswa tertarik.

Hal ini ditunjukkan oleh respon siswa terhadap materi pelajaran, LKS, materi ajar siswa, suasana belajar, cara guru mengajar, dan tahapan-tahapan yang diarahkan guru dalam proses pembelajaran. Hasil penelitian menunjukkan bahwa $100 \%$ siswa berminat mengikuti kembali proses belajar mengajar dengan model Cooperative Scripts ini.

Tingginya ketertarikan siswa tuntuk mengikuti model pembelajaran Cooperative Scripts sangat wajar, karena rasa ingin tahu siswa dan langkah dalam pembelajaran berkaitan erat dengan kehidupan seharihari siswa yaitu mengungkapkan materi dengan gaya bahasa siswa itu sendiri bersama teman untuk memahami konsep yang mereka pelajari (Miller, 2008).

Suasana belajar yang menyenangkan akan membuat siswa dapat menerima pelajaran dengan baik. Berdasarkan data diperoleh bahwa suasana belajar yang terjadi selama pembelajaran menarik bagi siswa, terbukti karena $100 \%$ siswa menyatakan tertarik, hal ini mengindikasikan bahwa penggunaan model pembelajaran Cooperative Scripts membuat siswa antusias mengikuti pelajaran.

Cara mengajar guru mendapat respons positif dari siswa sebanyak $100 \%$ siswa merasa jelas dengan cara guru mengajar. Hal ini menunjukkan bahwa tahapan pembelajaran dengan model Cooperative Scripts menarik bagi siswa dengan respon positif yang tinggi terhadap cara mengajar guru, diharapkan hasil belajar terutama pemahaman konsep siswa meningkat. Dari data respon siswa juga diperoleh bahwa pembelajaran dengan model Cooperative Scripts dapat membantu siswa dalam menjawab butir soal dalam tes pemahaman konsep siswa yang memiliki kesulitan yang cukup tinggi terutama dalam menganalisis data. Siswa terlihat sangat berminat dengan pembelajaran Cooperative Scripts ini, namun siswa sangat memerlukan bimbingan guru untuk mengatasi kesulitan dalam sintaks pembelajaran tersebut karena model Cooperative Scripts ini relatif sangat baru diterapkan dalam pembelajaran IPA, sejalan dengan guru melakukan bimbingan belajar untuk memastikan agar siswa mengalami keberhasilan pada saat dia menerapkan konsep atau keterampilan yang baru (Kardi, 2005).

Secara keseluruhan, siswa memberikan respons positif terhadap pembelajaran. Respon positif siswa menunjukkan bahwa siswa antusias dengan pembelajaran yang disajikan. Hal ini dapat memotivasi siswa untuk meningkatkan perhatian dan membuat mereka terlibat dalam pengalaman pembelajaran yang menyenangkan dan bermakna (Nur, M. 2010).

\section{Hambatan/Kendala dalam pembelajaran}

Kendala yang ditemui selama dalam pelaksanaan pembelajaran di kelas, dengan menerapkan model Cooperative Scripts hanyalah kecanggungan siswa karena merupakan model pembelajaran baru sehingga perlu penyesuaian serta bimbingan dari guru. Guru harus pandai memotivasi siswa dengan menyemangati para siswa untuk berani tampil, berbicara di depan kelas, dan belajar mendengarkan/mengkoreksi pemaparan materi dari rekan satu kelompoknya.

\section{KESIMPULAN}

\section{A. Simpulan}

Berdasarkan hasil penelitian yang telah dilakukan dapat disimpulkan bahwa perangkat pembelajaran IPA model Cooperative Scripts yang dikembangkan layak dengan kriteria baik meliputi syarat validitas, kepraktisan, keefektivan. Hasil implementasi di kelas terbukti dapat meningkatkan dan berpengaruh terhadap pemahaman konsep IPA siswa serta keterampilan berkomunikasi siswa di Sekolah Dasar khususnya pada pokok bahasan materi sistem pernapasan pada manusia.

\section{B. Saran}

Berdasarkan hasil penelitian yang telah dilakukan, disarankan bahwa hendaknya sebagai guru pengelola kelas untuk perlu lebih memperhatikan pengelolaan waktu dan pembimbingan siswa agar pembelajaran dengan menggunakan model Cooperative Scripts dapat terlaksana dengan baik. 


\section{REFERENSI}

Arends, R. I. (2008). Learning to Teach. Yogyakarta: Pustaka Pelajar.

Amir, Mohammad Faisal. (2006). Mengolah dan membuat interpretasi hasil olahan SPSS untuk penelitian ilmiah. Jakarta: Edsa.

Anderson, Lorin W., Krathwohl, David R. (2001). A Taxonomy for Learning, Teaching and Assessing. London: Addison Wesley Longman, Inc.

Bonk, Curtis. (1998). Cooperative Learning \& Teaching best of Bonk Handout. Diakses melalui $U R L$ :

http://www.indiana.edu/bobwed/Handout/script. html pada tanggal 24 April 2014

Degeng, N. S. (2013). Ilmu Pembelajaran. Bandung: Aras media.

Dimyati., Mudjiono. (2009). Belajar dan Pembelajaran. Jakarta: Rineka Cipta.

Felder, R. M., Brent, R. (2003). "Learning by Doing". Chem. Engr. Education 2003, 37, 282- 283, diakses melalui http:// www.ncsu.edu/felderpublic/Columns/Active.pdf per tanggal 24 April 2014.

Fraenkel. (2008). How to design and evaluate research in education. New York: McGrow-Hill Company.

Guyton, A. C. (2012). Fisiologi Kedokteran. Penerjemah: dr. Brahm U. Pendit. Jakarta: Penerbit Buku Kedokteran EGC.

Ginnis, Paul. (2008). Trik \& Taktik Mengajar. Jakarta: PT. Macanan Jaya Cemerlang.

Hadi, S. (2007). Pengaruh Pembekalan Model Cooperative Script Terhadap Ketrampilan Berfikir Kritis, Ketrampilan Metakognitif, dan Hasil Belajar Biologi Pada Siswa Laboratorium UM. Malang: UM.
Hakim, A., Liliasari., Kadarohman, A. (2012). "Student Concept Understanding of Natural Products Chemistry in Primary and secondary Metabolites Using the Data Collecting Technique of Modified CRI". International Online Journal of Educational Sciences, 544553.

Ibrahim, M. (2012). Konsep, miskonsepsi dan cara pembelajarannya. Surabaya: Unipress.

Ibrahim, M. (2005). Asessmen Berkelanjutan konsep Dasar, Tahapan Pengembangan dan Contoh. Surabaya: Unesa University Press.

Kardi, S. (2005). Mengembangkan Tes Hasil Belajar.Surabaya: Unipress.

Miller, B. (2008). The multigrade classroom: A resource handbook for small. rural schools. Portland, OR: Northwest Regional Educational Laboratory.

Nur, M. (2010). Strategi-strategi Belajar. Surabaya: UNESA- University Press.

Pavio, A. (2006) "Dual Coding Thery and Education". Draft chapter for conference on Pathways to Literacy Achievement for High Poverty Children. University of Michigan School of Education.

Sharan, S. (2012). The Handbook of Cooperative Learning. Penerjemah: Drs. Marianto Samosir, S.H. Yogyakarta: Familia.

Slavin, R. E. (1996). "Research for Future. Research on Cooperatng Learning and Achievement: What We Know, What We Need to Know". Contempory Educational Psychology 21, 43-69 (1996)

Slavin, R. E. (2011). Psikologi Pendidikan: Teori dan praktik. Jakarta: Indeks.

Trianto. (2007). Model Pembelajaran Inovatif Berorientasi Konstrutivistik. Surabaya: Pustaka Ilmu. 